\title{
METAPRAGMATICS IN A COURTROOM GENRE
}

\author{
Isolda E. Carranza
}

\begin{abstract}
Taking as a starting point a broad conception of metapragmatics (Lucy 1993), this study describes a wide range of reflexive elements in closing arguments of criminal trials, and on the basis of their habitual use by trial lawyers, it enquires about the general underlying function as part of the sociocultural practice (Bourdieu 1990). The corpus of was collected at twenty-two criminal trials observed and recorded by the researcher. Five kinds of metapragmatic indexes - from the maximally explicit to the implicit - are identified and analyzed in their interactional, situational and societal context: (1) performatives, which count as official acts by the trial lawyer, (2) formulations and other evaluations of speech, (3) descriptions of aspects of the sociocultural practice and allusions to the principles governing the event, (4) strategic descriptions of contextual conditions, which are exploited with group identity and relational effects, and (5) style. The analysis reveals that these metapragmatic features contextualize the communication as expressing a specific social capital, and at the same time, they contribute to define what does not count as legitimate practice. Apart from the specific effects of individual types of indexes, in closing arguments metapragmatic indexes basically function signaling that the social actor and the practice they are engaged in rightfully belong to the social field of the law.
\end{abstract}

Keywords: Social field; Metapragmatics; Social practice; Law; Courtroom discourse; Closing arguments.

\section{Introduction}

At the stage of the closing arguments in a criminal trial, the prosecuting and the defending lawyers' speech can be examined in at least three facets: a) Certain speech acts must be performed which are inherent to the role of prosecutor or defense lawyer. b) A text must be produced that establishes connections with preceding texts, e.g. testimonies and expert witnesses' statements, and with itself. c) A view is expressed on the speech event itself, the trial, as a concrete social occasion (the particular trial being carried out) or as a category of events (all trials in the abstract). Consequently, in closing arguments we find abundant signaling of pragmatic aspects of the speech event, manifestations of shared beliefs about the institution of the Courts, the social practice, the participants, and the principles that underlie it. In order to explore this, it is appropriate to apply an understanding of metapragmatics as general reflexive activity and encompassing metasemantics. (Lucy 1993). This paper examines various types of reflexive elements in a corpus of closing arguments of criminal trials with the aim of identifying the functions of metapragmatics in the sociocultural practice of administering justice.

The central concept that captures the phenomenon under study is 'metapragmatics' understood broadly in line with Silverstein (1993) and Jaworski, Coupland \& Galasiński (2004) as a general semiotic function that allows for reference 
to language and the products or the processes of language use, resulting in manifestations which are metalinguistic, metatextual, metadiscursive, or metacommunicative. The renewed interest in metapragmatics is associated to a wealth of studies on various framing devices, verbal art and play, stylization, metadiscourses and language ideologies. The terms 'reflexive' and 'reflexivity' will be used occasionally in a non-specific fashion. Metapragmatics comprises a variety of elements at different levels of discourse organization, so the forms that will interest us range from minimal grammatical categories, such as verbs, first person morphemes, and noun phrases, to predications and attributions, to the overall co-occurrence of features which we call style. The starting point is to observe individual oral texts produced in interactions which are considered concrete instances of a more abstract construct, the social practice. A focus on the metapragmatic dimension of the language used will illuminate aspects of interactional processes and, indirectly, aspects of the practice that includes them.

The data were collected through observation of twenty criminal trials in the city of Córdoba, Argentina, that are being examined in a broader research project (Carranza 2003, 2004, 2006). The subcorpus of closing arguments, tape-recorded and transcribed by the researcher, is the basis for this paper. The fact that the country's legal system is based on Roman law does not imply that it is not adversarial, on the contrary, it embraces the conception of the judge as an impartial arbiter mediating between two opponents just like do systems based on common law. ${ }^{1}$ The standard format in criminal courts in Argentina is the trial by bench with three acting judges, though some jurisdictions occasionally apply alternative formats. For example, at the request of either party, homicide cases may be tried by three judges along with two members of the public who are selected to be the non-professional members of the tribunal. The corpus of this study includes trials with this kind of court. The presiding judge directs the proceedings. Closing arguments are primarily and directly addressed to the court, regardless how it is made up. The duration of the closing arguments of the corpus ranges from 45 minutes to over three hours, with the average being two hours. Since in a single trial there may be more than one defendant, in such cases more than one counsel for the defense were recorded per trial. On the other hand, since any given prosecutor is usually assigned to a single Court, some of the prosecutors were recorded twice.

\section{The object of study and the theoretical perspective}

Closing arguments have been examined with different research agendas which include foci as diverse as the conceptual scene-setting achieved through metaphor Cotterill 1998, 2003) and trial lawyers' storytelling (Amsterdam Hertz 1992). Just as the study of courtroom speech and the linguistic analysis of legal processes have yielded insights into the workings of power (Conley \& O'Barr 1990, 1998; Matoesian 1993, 2001), the study of closing arguments is a fruitful venue of research into the relationship between language use by professionals and the legal social field. They constitute a quintessentially reflexive genre because they are a component of the trial which must

\footnotetext{
${ }^{1}$ Regardless of having Roman law basis or not, criminal processes are not adversarial when judges carry out the criminal investigation before the trial and produce a verdict as well.
} 
contain interpretations of the speech produced during the previous days of the trial and interpretations of the actions and speech in progress.

In her analysis of a civil trial, Stygall (1994) shows that the opening statement was composed primarily of metacommunication and that jurors found the metacommentary difficult to understand when it was about legal discourse and when it signaled the end or the beginning of a discourse topic. A distinct feature of the two final arguments in that trial was a substantial increase in the use of a knowledge base expressed in direct or indirect reported speech. Represented discourse was witnesses' testimony from the immediately preceding evidence stage.

Another study of courtroom interaction finds that explicit metapragmatics on the part of the experts becomes "a mechanism of control over the communicative expectations of participants" (Jacquemet 1996: 179). Going beyond the interactional negotiation of the conditions through which truth is constructed, Jacquemet acknowledges that there is "a normative [...] dimension in all explicit resorts to metalanguage - a dimension that is related to group identity, social stratification, and power asymmetry." (Jacquemet 1996: 162). This connection between a normative dimension and group membership will also be detected in the analysis of closing arguments.

Mertz (1994) has argued that the study of the linguistic structuring of social life in the domain of law is important because the law is a key locus of social power which is channeled linguistically. In view of the present research goal of observing the constitution of social meaning through reflexivity in forensic discourse, the analysis must transcend the interactional and the textual levels. Such aim calls for a theoretical framework that accounts for the relations between discourses and power in society, and to that strand I turn now.

The concept of social practice leads us to examine power strategies and relations in a social field. In Bourdieu's sociology, field denotes a historically constituted social space with specific institutions, specific capital, common interests, and a system of structural positions for the social agents and relations between positions. The concept of social field leads us to notice the prosecution of interests (either individual positions' or general field interests), competition for the capital in question, and struggles with other social spaces over the relative value of their capital. In the data of this study, the interests at stake include ratifying the speaker's position as a legitimated member of the field (in relation to the other field members) and ratifying the legal field as a social space for experts (in relation to lay individuals).

Since we will be dealing with the administration of justice, it will be useful to apply the concept of 'social field' that Bourdieu $(1977,1990)$ uses to denote a configuration of positions defined by a particular distribution of capital, such as the field of science, religion, economics, sports, etc. The field of the law, then, is a social space with its specific capital where any given position holds objective relations to other positions and any given institution holds objective relations to other institutions within the field. The concept of field allows the analyst to consider the existence of a field ideology (specific beliefs and a general world vision), a field logics (connections between states of affairs and social relations), and a characteristic way of acting, speaking or seeing. Under this light, we will deal with a discourse of authority produced in an official situation by authorized agents who derive their symbolic capital from the state. As the analysis of the data proceeds, it will become clear that, by conceiving the 
research subjects as acting from their position in the field of the law, valuable insights are gained into the identified discourse strategies and institutional ideologies.

One inescapable theoretical strand this paper draws upon is the linguistic anthropological one that has dealt with metapragmatics. Research in this area usually has its roots in the thought of Bateson (1972) who was interested in human verbal communication in general and argued that it operates "at many contrasting levels of abstraction" (1972: 177) one being the metalinguistic set of abstract levels, another the metacommunicative set. In other words, metacommunicative messages do not occur at a single, homogeneous level. Accordingly, the data to be analyzed in this paper are diverse.

Bateson found that play, threat, histrionic behavior, and deceit, where actions denote other actions, would not be possible without the ability for metacommunication. The essential role of metacommunication in communication has been recognized in linguistics (Jacobson 1960) and in anthropologically oriented pragmatics (e.g. Silverstein 1993; Hanks 1996). The latter extends Bateson's contention and acknowledges that 'all verbal communication is self-referential to a certain degree, that all language use involves a constant interplay between pragmatic and metapragmatic functioning' (Verschueren 1999: 195). The questions posed in this paper are: What kinds of metacommunication are there in closing arguments? And what is the social function of habitual metacommunication by the expert participants in a speech event where institutional power is at stake?

Silverstein (1993) has argued that 'pragmatics is the semiotic realm of indexical meaning' (1993: 41-42) and that "signs functioning metapragmatically have pragmatic phenomena $[\ldots]$ as their semiotic object; they thus have an inherently "framing," or "regimenting," or "stipulative" character" (1993: 33).

This paper incorporates Silverstein's notion that there are degrees of explicitness in this phenomenon. What he calls 'strong explicit metapragmatics' gets entextualized through reference or predication by means of elements of the lexicon or the grammar, whereas implicit metapragmatics may include non-verbal behavior, the poetic function which is present, for example, in metrics, and decontextualized texts that become repeated formulae. In turn, there is a lamination of strata of metapragmatic-pragmatic regimentation. For example, an explicit report or description of an interaction belongs to the lowest-stratum metapragmatics, while the multiple, overlapping functional strata culminate in a co-textual implicit metapragmatics (Silverstein 1993).

Reported discourse, a form of metalanguage, is excluded from this study because it has been intensely investigated in various oral genres (e.g. Briggs 1993) and courtroom discourse (Matoesian 2001) including closing arguments (Stygall 1994) which have already been analyzed following Bauman's \& Briggs's (1990) insightful approach on intertextuality and recontextualization (Carranza 2001, 2007). Other kinds of discourse representation, for example the participants' naming of what they are doing, are part of what is accounted for in this study. In the effort of understanding verbal behavior, "the actors' interpretations become part and parcel of what needs to be described and explained." (Verschueren 2000: 445). The significance of the 'meta' level has been acknowledged recently with the publication of a collection of papers (Jaworski, Coupland \& Galasiński 2004) that examine a diversity of issues involving metalanguage, metapragmatics and metadiscourses. Studies of metalanguage have consistently noticed that it is a site for the expression of ideologies of language (e.g. 
Preston 2004). In the course of the present exploration, too, ideological representations of language use will inevitably be found.

\section{Kinds and degrees of explicitness of metapragmatic signaling}

This part of the paper organizes the analysis of metapragmatic indexicals in the data into five sections. The first section groups performative uses of verbs, and the second one includes evaluations of the meaning and the communicative status of what was said. The third section deals with descriptions of the sociocultural practice, in other words, 'the rules of the game', while the fourth section is about indices of current contextual conditions, especially the identity and relational functions found in indices of actual participants. Finally, a set of normally co-occurring stylistic features is reviewed in the fifth section.

\subsection{Performatives}

A demand typical of juridical genres is that certain speech acts be made explicit which are key to the communicative goal pursued. Hence, the first person singular form of performative verbs in written genres, e.g. protesto 'I protest', lego 'I bequeath'. The subject of the performative verb is whoever acts in their legal capacity as in doy fe 'I attest'. We are here concerned with the cases in which the performer of the predicated act is the speaker although, as it will be shown below, the grammatical realization can be either first or third person singular. The occurrences of verbs of speaking used with performative function in this way are easily recognizable as elements which are constitutive of the genre closing argument.

In these cases the participant's speech act gets an unequivocal, face-value interpretation and is given prominence by its very surface realization in the first-person present. At the same time, there is a full-fledged self-reference that constitutes a type of strong deictic anchorage in the context of situation. Some speech acts pertain to the situational role of the speaker in the institutional speech event, as when a defense lawyer says niego los cargos, 'I deny the charges'. The fragment below is the end of a closing argument. The verb tense chosen is a periphrastic future but it has the meaning of the expected present tense:

(1) (Prosecutor Rosso) Por lo precedentemente mencionado, es que voy a solicitar que se declare a los imputados Balbuena y Maidana, presentes en esta sala de audiencia, coautores responsables de los delitos de robo calificado por el uso de armas y tenencia de armas de munición de guerra

'For the foregoing reasons, I am going to request that the accused Balbuena and Maidana, present in this courtroom, be found guilty of the crimes of robbery aggravated by the use of firearms and possession of war-ammunition weapons'

The frequent use of the grammatical third person for this performative function is an instance of stylistic variation which increases the degree of formality of the register. 
(2) esta defensa pide la absolución,

'This defense requests acquittal.'

The maximum degree of explicitness in metapragmatic semiosis is found in the use of performatives, where the doing coincides with signaling the doing. Following Austin (1962), we can call the performative expressions like niego 'I deny', voy a solicitar 'I am going to request', and pide [this defense] 'asks' primary.

The interest of these occurrences for the purposes of the present study lies in the fact that they indicate the speaker's ability to monitor and define their own language production. At the same time, they point to the fact that in this type of social practice the social actors are aware that naming what they do is a necessary and sufficient condition for doing it. The institutional acts illustrated above fall into the class of acts that can be considered "acts of institution (in the active sense)" (Bourdieu 1998: 40) by public officials. Because of the first person verb morphology, these performatives also index the individual participant, but this is dealt with in section 3.4. below.

\subsection{Evaluations of speech}

A second kind of explicit metapragmatics consists in an evaluation of speech through labeling. The referent is either something that has been said during the trial or that is being produced by the speaker (lawyer). It comes in the shape of nominal formulations and non-nominal qualifications of speaking.

a) Nominal formulations:

(1) contradicción 'contradiction'

(2) artilugio 'trick'

(3) estratagema 'stratagem'

(4) maniobra 'manoeuver'

(5) disenso 'dissent'

(6) salvataje 'rescue operation'

Labeling the recent events is a form of reification. Granting speech a fixed entity allows for further reference in the same closing argument and for discursive management, for example, as part of argumentative chains. It can plausibly be argued that, on the interactional plane, defining reality is trying to control it. Accordingly, to define a social situation with this kind of evaluative naming is a way of establishing the situation as one of a certain type. The importance of strategic lexical choices by trial lawyers has long been recognized (Cotterill 2004 for a review of antecedents in this respect). As Eades (2006) points out, legal training often includes teaching future lawyers to choose labels in order to control the way that people and events are perceived.

b) Non-nominal qualifications of speaking:

(7) así quedaba acreditado que ...

'in this way it was proven that [...]'

(8) dijo muy suelto de cuerpo 


\section{'said in a very happy-go-lucky way'}

The evaluation of speech we are observing belongs to a stratum distinct from that observed in section 3.1., at which denoting a speech action amounts to doing it. Group (a) is that of the forms already available in the lexicon, while (b) is the group of predications about the co-text or the text in progress.

Representation is an intrinsic component of the genre closing argument. It is a venue for the confrontation between the parties in conflict. As a result, reflexive denotations of the texts by Self and others serve the trial lawyer's rhetorical ends. The following case illustrates an attack on a defense witness and her testimony by these means. Additional forms of metapragmatic indexing appear underlined and will be described in later sections.

(9) (Private Prosecutor Pedraza) *Recuerdesé bien esto que ella no tenía nada que decir en contra de Atampiz. Estaba sin embargo muy inquieta y perturbada. Al extremo que fue necesario atenderla médicamente. Y luego se produce lo que yo llamo el derrumbe emocional de la señora de Arsani, tironeada entre la menTIRA que venía a relatar, y la verdad de los recuerdos que venía a ocultar. 'Remember very well that she had nothing to say against Atampiz. She was, however, very restless and upset. To the extent that it was necessary to assist her medically. And then what I call Mrs. Arsani's emotional collapse took place, she was pulled between the lie that she came to recount, and the truth of the memories that she came to hide.'

The fragment shows metacommunicative qualifications of the lay participant's speech behavior (el derrumbe emocional 'the emotional collapse', no tenía nada que decir 'had nothing to say', relatar la mentira 'recount the lie', ocultar la verdad 'hide the truth') along with other indexicals (yo 'I', llamo 'call [first person]'). The lawyer constructs a version of the events that negatively characterizes the witness and, as a consequence, the testimony deflecting attention away from the witness' words while focusing on details designed to discredit them.

The structure and use of the evaluative formulations of speech which have been dealt with in this section are far from constituting a courtroom restricted usage or manifesting a technical register (unlike fixed performative expressions like solicito subsidiariamente 'In the contingency that my first request is not granted, I request' or ejerzo la defensa material 'I exercise the material defense'). On the contrary, these evaluations are common in everyday interaction. This type of realization of reflexivity seems to be the least specifically institutional since metasemantic and metapragmatic references of this kind are common in ordinary language. They serve as interpretations of communication, as they do in courtroom discourse. They play a key function in the speech event under study because the interpretation or evaluation of witnesses' talk and of procedures which preceded the moment of speaking is what closing arguments consist in for the most part.

A study of narratives in closing arguments reveals that the narratives about the allegedly criminal events that led to the trial and even those about later events (such as recognition of suspects) during the preparation stage of the legal case are considerably outnumbered by the narratives about the events that took place in the courtroom as part of the trial (Carranza 2003). In the data presented here, again, the characterization of 
testimony and evidence appears as a core component of closing arguments by which the lawyer attempts to focus the court's evaluation on the trial itself, the witnesses' demeanor, and the quality of the evidence rather than on the criminal events in the more distant past.

The nominal and non-nominal evaluations we have seen in this section are an expression of the confrontation between parties that lies at the basis of the adversarial system and clearly serve as a potent persuasive strategy. The lawyer's labeling of conduct is oriented to induce the audience to adopt the lawyer's interpretation of that conduct. The performatives and evaluations of speech reviewed so far consist in reference to particular, concrete speech actions, and constitute metalanguage. In the next section we move on to a different kind of metapragmatics.

\subsection{Descriptions of governing principles or other aspects of the sociocultural practice}

The third type of metapragmatics is reference to ideas which underlie the entire practice, its foundations, the rationality which sustains the practice. As is to be expected, in the closing arguments there are often intertextual relations with foundational texts by outstanding jurists. There is an explicit mention of the justice system when what is named is either the activity in general (e.g. reconstruir la verdad histórica 'to reconstruct the historical truth') or the way it is carried out (e.g. la sana crítica 'sound critique' and el sentido común 'common sense'). The rules of the game, in Wittgenstein's sense, are made explicit.

The norms of interaction in a trial demand that the closing argument display the application of the faculty of reason and common sense on the one hand, and on the other, congruence with the facts and with the legal rules. This reasonability standard is often referred to explicitly by the participants in the speech event, as illustrated in (1) below. In this way, the text itself offers metapragmatic evidence about the norms of the speech event which are shared by the community of experts.

(1) (Defense attorney Vera) No se puede acreditar por parte testimonial ni tampoco por los dichos del propio imputado, es decir por su confesión. El sistema de la sana crítica racional, hace que no solamente para acreditar un resultado con carácter de certeza deba recurrirse a una prueba de carácter directa, sino también a indicios serios, vehementes y concordantes que yo creo que se dan en este caso.

'It cannot be proven by testimonies nor by the sayings of the accused himself, that is to say his confession. The system of sound rational critique, determines not only that in order to prove a result to the degree of certainty evidence of a direct kind must be produced, but also serious, vehement and coincidental cues which I think there are in this case.'

Most trial lawyers observed in this study give explicit formulations of ideas about what they and the judges do (e.g. applying common-sense rationality) in events of the type they are engaged in at the moment of speaking. The prescriptions voiced in these formulations are part of the dominant ideology in the institution which is inculcated through the socialization of future lawyers. This view is compatible with Mertz's (1998) observations of law school classroom discourse. She detected points of 
conflict and metapragmatic struggle which are resolved by the professors' regimentation of students' speech, for example, by directing the students to repeat, calling a chunk of speech legal argument, and appropriating the students' voice in dramatized dialogue. This is interpreted by Mertz, not just as the translation of a social reality into legal categories, but as the inculcation of an institutionalized linguistic ideology, a legal ideology, and a professional identity onto the students.

Another key aspect of the use of speech to refer to the institutional activity being carried out is the fact that through such speech the speaker displays professional competence and manages to create a legal reality. Excerpt (2) illustrates this.

(2) (Public defense attorney Gutiérrez) Respecto de esta acusación, mi defendido optó por el silencio. Silencio que como la ley lo establece, no implica ninguna presunción de culpa en su contra. Esto quiere decir que la prueba de cargo, debe ser de tal magnitud, que permita desvirtuar el principio de inocencia del que goza. No está a su cargo ningún tipo de prueba.

'As regards that accusation, my defendant chose silence. Silence which, as established by the law, does not imply any presumption of guilt against him. This means that the evidence must be of such magnitude that it allows the Court to override the principle of innocence which applies to him. He does not need to provide any evidence.'

The genre and register dimensions connect these descriptions of the practice and statements of its underlying principles to the situation type and the participant category. Clearly, the central communicative goal is not to announce or to inform the basics of the principles that guide the activity. At the interactional level, the positioning of the text producer is that of a competent actor who knows the norms of interaction for the speech event and shares with the community the standards for that communicative event. In other words, positive self-presentation is served indirectly by this form of metapragmatics. References to the institutional guidelines and foundations for action not only project the speaker as knowledgeable of the rules, also implicitly define what the speaker is doing as conforming to those rules. The trial lawyer manages to present their move as living up to these overt standards. At the level of the social practice, making the norms for acting explicit keeps up an awareness of their existence and legitimates the social position of the expert. This mechanism reproduces the established model for this institutional speech event and ratifies the exclusion of the non-experts. The formulations of institutional ideologies about the trial and the practice of judging contribute to preserving the field of the law in its local, habitual configurations.

\subsection{Strategic descriptions of current contextual conditions}

In this section, we will observe various kinds of linguistic forms which act as metapragmatic indexes by signaling contextual factors such as participants, the situation, or elements of the situation. We will be particularly interested in indices of participants (including Self), with relational and ideological functions.

The core of a trial as an event lies in the confrontation of opposing interests, consequently, we may expect the divergence itself to be an object of explicit reference, predication or qualification. The following segment shows this. 
(1) (Defence attorney Rosales) Ahora me voy a referir al fiscal a quien yo le tengo el mayor de los respetos, pero en este momento voy a discrepar con él. Cuando él empezó su alegato ayer dijo "las pruebas son las que absuelven o condenan los imputados", yo cuando dijo eso sentí un gran alivio, dije "bueno, creo que es la absolución de Mercante", porque si las pruebas son las que absuelven o condenan, usted doctor tendría que haber pedido la absolución de Mercado. Acá no existeØ .. elementos de prueba, no existe ningún elemento de prueba para decir que Mercante es el culpable del hecho que lo están involucrando,

'Now I am going to refer to the prosecutor for whom I have great respect, but at this time I'm going to disagree with him. When he started his closing argument yesterday he said "it is proofs that acquit or condemn the accused", when he said that I felt a great relief, I said "well, I think this is Mercante's acquittal", because if it is proofs that acquit or condemn, you, counselor, should have requested Mercante's acquittal. There aren't any pieces of evidence here, there is no evidence to say that Mercante is guilty of the actions he is being accused of.'

Like most defense attorneys observed in this study, the speaker of (1) above, who reproaches the prosecutor for accusing her defendant on feeble grounds, does not miss the opportunity to be congenial with that colleague by means of a quien yo le tengo el mayor de los respetos 'for whom I have great respect'. The clash between the legal adversaries is here manifest in the evaluative reference to a preceding move by the prosecution, that of requesting conviction instead of acquittal.

Hobbs (2003) interpreted a Detroit prosecutor's use of AAVE and replacement of the statuses 'prosecutor' and 'juror' with 'me' and 'you' as a persuasion strategy based on impression management. The data of this study reveal a much more complex dynamics than impression management, and one that exceeds the interpersonal realm. In the next excerpt, there are indices of five entities: The judges of the bench, the noninstitutional audience, criminal trials in general, the specific trial that is in course, and the development of the testimonies.

(2) (Private prosecutor Pedraza) y no se vaya a decir que este tribunal no se ha caracterizado por un trato muy humanitario para con $\downarrow$ todos. Para los que no van- no concurren nunca a un juicio les informo que hay juicios que parecen una carnicería. Las situaciones que vive la gente. Aquí todos tuvieron sus derechos.

'And it cannot be said that this Court is not characterized by a very humanitarian treatment to $\downarrow$ everybody. Those of you who don't go- don't attend trials I inform you that there are trials which seem a slaughterhouse. Due to the situations people live there. Everybody had their rights here.'

The abundant indexing of the co-present expert participants shows that trial lawyers strive to establish and enhance their relationships with the other law professionals. This effort is observable in the preceding example and is also apparent in all the subsequent ones. The performative verb ('to inform') and the explicit reference to the addressees ('those who do not attend trials') single out the set of non-experts who 
need to be told what trials are like. By way of implicature, the in-group gets defined as well. It is interesting to notice that this intimidating description of trials, which is addressed to the audience - mostly relatives of the two accused youngsters - seems to also refer to the treatment of witnesses ('everybody'), in other words, individuals who are not being tried. Most importantly, with the adjective 'humanitarian' standing for 'respectful' in this context (and within an argument that the judges have been very patient with some reluctant witnesses), it praises the way the intervening judges conducted the trial that is concluding. Praise of the court or the prosecutors by private trial lawyers is frequent, though not usually reciprocal.

In the following segment, the use of inclusive 'we' indicates that members of the legal profession are the reference group in comparison to which another group will be evaluated. This trial lawyer is actually attempting to exonerate the defense witnesses from their inability to answer the detailed questions asked by the prosecutor.

(3) (Public defense attorney Galli) Ni siquiera nosotros, que por designio de Dios o no sé por qué, pertenecemos a un segmento social, y de alguna manera somos privilegiados, no podemos recor- yo no recuerdo qué comí antes de anoche, [... omitted utterances ...] Entonces si a nosotros que somos personas que supuestamente tenemos .. estudios, tenemos un lenguaje- supuestamente técnico, se nos pasan esos detalles, en momentos importantes para la vida de uno, $[\ldots]$

'Not even we, who by God's design or I don't know why, belong to a social segment, and in some way are privileged, cannot remem- I don't remember what $\mathbf{I}$ ate the night before last, [... omitted utterances ... ] Then if we who are people who supposedly have .. studies, we have a supposedly technical language, we miss details in moments that are important for one's life, [...]'

This defense attorney develops an explicit we-them contrast which is meant to establish the 'we/I' as the standard with which others are measured. In this lawyer's reasoning, the Others' social disadvantage is supposedly an argument in their favor. In addition, ideologies of language use are applied to the representation of users in terms of outgroup or ingroup in relation to the social field of the law. The representation of this divide between the public and the experts associated to state power, with their respective linguistic competence, is akin to the processes studied by Gal and Woolard (1995) which establish authority and social hierarchy by representing social groupings and their use of language. Later in the same closing argument, the lawyer admits that those who evaluate her own witnesses negatively are numerous. The continuous unfavorable representation of witnesses simply results in an unflattering contrast with the co-present middle-class, educated lawyers, most of whom are institutionally affiliated with the courts.

In (4) below, another counsel for the defense works at the projection of a Self by establishing relationships of association, similarity or solidarity with the acting judges.

(4) (Defense attorney Lafour) Como final, leyendo a un autor italiano, Pietro ( )- qué le voy a decir al Tribunal, si han sido muchos hasta mis profesores, pero él decía qué difícil la tarea del, del Ministerio Fiscal, de una cámara. Parece un oficio usurpado a los dioses. 
'In closing, reading an Italian author, Pietro ( ) - what can I tell the Court, if many have been even my teachers, but he'd say the Public Prosecutor's task, a Court's task is so hard. It's a job usurped from the gods.'

This text also illustrates the usual overlap between the social networks associated to judicial posts and those of law school professors and instructors. In the judicial milieu, holding a university position is an additional source of prestige. The defense attorney of (4) strives to turn the stated common ground to his advantage, but since this move is hardly a substitute for a legal argument nor affects the trial outcome in his client's favor, it is clearly an indication of politeness aimed to accrue personal gains.

It is significant that these alignments of identification do not apply exclusively to the judges, but are also often directed to the rival attorneys. The basic interactional objective of positive Self presentation is pursued through identity-oriented alignments with the group of experts, regardless of the situational role of adversary. The target addressees of moves of deference or allusions of similarity are the professional participants of the social encounter, who most of the times are also permanently employed at the courts (e.g. the prosecutor, the two assistant judges, the president).

An interpretative perspective which goes beyond the speech event type and the institution is needed to explore the convergence of institutional participants' multiple social roles (which get alluded to in the course of this practice, and as a result, are made relevant in it). To this end, the concept of field has the appropriate scope because it lends itself to accounting for trial lawyers' allegiance across adversarial lines and for their moves of identification based on university training or other social practices in the legal field.

\subsection{Style}

Danet (1997) studied wills in Old English that have survived from the Anglo-Saxon period when creating documents was a novelty. The scribes included metacomments about the act of writing (e.g. I Ealdorman Alfred command to be written and made known...) and often transferred performativity to the written documents through the use of the first person linked to the ceremony of bequeathing, and through other means to strengthen the act being performed: Curses, reference to witnesses, and most interestingly from the point of view of this paper, stylized binomial expressions. According to Danet, "The case for preoccupation with language qua language is especially strong when the pair is redundant, as in Old English for "house and home" and "statements and provisions"." (1997: 28).

The elements to be analyzed in this section derive from the language function to which Cameron (2004) refers in the following way: "it seems evident that poetic effects would not be possible in a semiotic system with no "meta" dimension nor could they be recognized by a language-user unable to function at a "meta" level of interpretation" (2004: 314). The 'meta' character of elaborate instances of forensic declamatory style cannot be given here the in-depth treatment it requires, but will be acknowledged as part of the mechanisms through which trial lawyers reflexively design their speech (Cf. Bell $1984,2001)$. The style of forensic oratory as it gets deployed in closing arguments is implicitly metapragmatic because it signals the courtroom setting, the expert participant, 
and most importantly, what is being done, i.e. the closing argument, rather than direct examination or any other procedure. To support this, let us consider the following quote by Silverstein:

"the characteristic condition of metapragmatic indexicality is coocurrence in configuration of indexicals that may also or otherwise be quite distinctly functioning qua signs. The configuration of indexicals [...] serves as a metapragmatic indexical signal of such-and-such textual event." (Silverstein 1993: 48).

The 'cooccurrence of features of style in configuration' acts indexically in that it signals the social practice in which those features are typical. The Spanish language features identified as associated specifically to the closing argument are of two kinds: Features originating in written discourse and performance features. The former are lexicogrammatical constructions generally perceived in institution of this study as marked for formality and characteristic of prosecutors' speech:

Nominalizations:

(1) (Public prosecutor Rosso) Además, la actitud o el despliegue realizado por los imputados determina, a criterio de este representante del Ministerio Fiscal, la firme determinación criminosa que ambos tenían.

'Besides, the accused's attitude or their behavior indicates, in this Public Prosecutor's opinion, the firm criminal determination both of them had.'

Gerunds with coordinating, sequential or adjectival function, in addition to its normal use indicating simultaneity:

(2) (Public prosecutor Rosso) Esto se compadece plenamente con las actas de aprehensión coincidiendo la prenda de vestir que presentaba Balbuena con la que expresara la testigo Mores.

'This is fully compatible with the arrest report. The garment which Balbuena was wearing coinciding with that mentioned by the witness Mores.'

(3) (Private prosecutor Bellone) la dirección del proyectil que ingresa por la zona orbicular derecha saliendo por el occipital a la altura del cerebelo.

'The direction of the projectile which enters [the skull] in the right orbicular area going out though the occipital in the cerebellum area.'

Past subjunctive in -ra used with the meaning of preterit:

(4) (Public prosecutor Rosso) como lo determinaran las pericias balísticas a las que recientemente hiciera referencia.

'As was determined by the technical analyses of the bullets to which I recently made reference.'

Past participle clauses (also known as absolute constructions):

(5) (Private prosecutor Bellone) Producido el hecho de esta manera, un sujeto que circulaba circunstancialmente por la vereda del frente [...]

'The event having occurred in this way, an individual who happened to pass by on the opposite sidewalk [...]' 
Complex sequences of syntactic structures ${ }^{2}$, which includes oversubordination and duplication of nouns followed by a relative clause. These two features are present in the following text segment:

(6) (Public prosecutor Ferrara) Se plantea una discusión en la que también interviene el propietario de la zapatilla, Diego Romero. Esto ya frente a la vivienda en la vía pública. Discusión en la que hay varios presentes, entre los que no está Juan Antonio González quien en ese momento se encontraba en el interior de la vivienda, pero [...]

'An argument begins in which Diego Romero, the owner of the walking shoes, takes part. This is already in front of the house in the street. Argument which is witnessed by several people, among whom Juan Antonio Gonzalez is not, who at that moment was inside the house, but $[\ldots]$ '

This last feature is also in example (2) in section 3.3 which contains the duplication of the noun silencio (silence) followed by a relative clause. Also typical of forensic oratory are rhetorical questions and triplets (Carranza 2003) which are performance features. Unlike the preceding set of lexicogrammatical resources, these performance features, which invite audience involvement, are abundant in closing arguments by the defense as well as those by the prosecution. The following are sample tokens:

(7) (Defense attorney Bisoglio) La ausencia de relación de causalidad es crucial, es manifiesta y es dirimente.

'The lack of a causality relation is crucial, it is manifest, and it is decisive.'

(8) (Defense attorney Mazzeri) ¿Y era previsible que Trucco fuera al bar? No, no era previsible.

'And was it foreseeable for Trucco to go to the bar? No, it wasn't foreseeable.'

Bauman (2001) observes that poetics and performance are reflexive in the sense of essentially consisting in foregrounding formal resources. ${ }^{3}$ The data of this study indicate that the two performance features illustrated above, rhetorical questions and triplets, are so pervasive and typical of closing arguments as to be considered indexical of the institutional event and the category of participants ${ }^{4}$. A related issue is that certain genres function to highlight the relation between speech style and persona (Bauman 2001). The closing arguments of the corpus qualify as genres highlighting the relation between style and persona because they are a preferred stage for some attorneys to enhance the deployment of stylistic resources put to the service of complex selfpresentation goals.

2 This item also includes the omission of subordinating conjunction que (that) before verbs in the subjunctive, e.g. solicito se tenga en cuenta la falta de antecedents (Gloss: I request $\varnothing$ the lack of antecedents be taken into account). This formal feature is not frequent.

3 Other performance features, such as direct reported discourse and historical present, are associated to the discourse of the lifeworld, instead of invoking the domain of the law and for this reason are not dealt with in this paper (Carranza 2004).

${ }^{4}$ The claim grounded on an extensive empirical study that triplets and rhetorical questions are constitutive of the genre closing argument (Carranza 2003) does not extend to propose that the metapragmatic indexes which are typically institutional are exclusive of this genre. 


\section{Discussion}

Closing arguments are inherently reflexive, being designed to produce and present a particular interpretation of the relevant events. The classification developed so far reveals the abundance and diversity of indexing as metapragmatics gets manifest in various planes or strata. Performatives (3.1.), evaluations of speech (3.2) and descriptions of aspects of the sociocultural practice (3.3) clearly (though not exclusively) serve the performance of trial lawyer's situational role. The following paragraphs deal with each of these three elements.

1. Producing a closing argument consists in legitimately performing certain acts, which are specific to that stage in a trial, in the capacity of prosecutor or defense attorney (e.g. requesting a sentence). With the performative expressions, the professional participants and their interactional move are explicitly signaled in the process of participating in the speech event.

2. Only to certain extent does a closing argument consist in formulating only how things were in the past for the victim and the accused. Rather, the trial lawyer's authoritative version of that past is presented by focusing attention to what has happened and is happening during the trial. In fact, the contrasting constructions of the communicative events that have taken place during the courtroom development of the case are the preferred object for the controversy between accusers and defenders. The reflexive language which centers on the trial itself is so pervasive in the data that it stands out as a genre-constitutive feature of closing arguments. ${ }^{5}$

3. Reference to what closing arguments, criminal trials, the justice system, etc. are about amounts to ratifying the speaker as an authorized participant acting within the canon of the practice. It serves the persuasive ends pursued in closing arguments because the lawyer's practice and the representation of reality which is offered are presented as warranted by the fundamental principles of the justice system. The various ways of anchoring the text in the interaction and of reflexively conceptualizing elements of the cotext and of the speech event are essential to perform the role of trial lawyer and to establish a version of the reality of the trial.

The remaining two features that have been described and illustrated are discussed next thus completing the sequence from the most explicit to the most implicit kinds.

4. Like descriptions of aspects of the sociocultural practice, indices of and predications about contextual conditions, like speaker, addressees, other participants, etc. (3.4) have the property of serving interactional ends by contributing to selfalignments and other-positionings. The latter type of reflexive elements is an indication of 'audience design' understood as 'Designing speech to achieve an anticipated personal or relational outcome' (Bell 2001: 34). However, this interactional function is superseded, at a social practice level of analysis, by the institutional nature of several

\footnotetext{
${ }^{5}$ Although in section 3.2 it was noted that evaluative formulations of speech are frequent in everyday interaction, the classes of metapragmatic indexes revealed in the present study (e.g. performatives and descriptions of the sociocultural practice) and the functions they are found to play (e.g. indexes of participants applied in creating affinity with peers and authorities) clearly indicate that the multiple strata of the metapragmatic - pragmatic regimentation (framing) can have a distinct field function.
} 
contextual factors: Situational roles, physical setting, speech event and its consequences for the life of the individual being tried. The authority evoked by defining the nature of the "game" enables the participants to claim to possess the specific capital of the legal field and to distinguish themselves from those who do not.

5. The stylistic configuration (3.5), like the rest of the features analyzed, indexes the social field. In a critical adaptation of Bourdieu's theory, Chouliaraki \& Fairclough (1999) emphasize the struggles involving the capacity to use a legitimated style which gives credibility to a vision of the world, and argue that "[linguistic capital per se] is part of the struggle for the constitution and classification of social (field) relations." (1999: 104). Their view helps to understand the findings of this study that concern style. We know that, partly as a result of their socialization in law school, lawyers, as a social group, have differential access to a professional register, but in addition, the data show that both the legitimated style and the metapragmatics of their closing arguments indicate and constitute a shared group membership and relations in a shared social field.

Metapragmatics, as has surfaced in the data, lies at the core of the interplay between the local interaction and the broader social level. It defines what the participant is engaged in as legitimate action from a structural position in the legal field. At the local, interactional level, it contextualizes the communication as expressing a specific social capital. Inevitably, what does not count as legitimate practice gets defined at the same time. At the same time, in examining reflexive features of discourse, we found indications of ideologies - mainly about the institution, the social practice itself, the law, but also about college educated vs. uneducated social groups, language use, and language users. The function of metapragmatics in closing arguments is one of delimiting what rightfully belongs to the social field of the law.

\section{Conclusion}

Further research is necessary to live up to Lucy's early programmatic statement: "An understanding of the reflexive capacity of natural language will be essential for an adequate understanding not only of language but also of all those spheres of life which depend on the use of language" (Lucy 1993: 29). This study, however, was intended as a small step in that direction working on the assumption that at the level of the interaction social practices are reproduced or transformed, and their examination is a way towards structural levels like social field. It focused on a courtroom genre as a component of the practice of administering criminal justice.

At the outset of this study it was recognized that closing arguments are inherently reflexive since at the closing argument stage, the events of the trial are represented, formulated, narrated and evaluated. However, little was known of the diversity, complexity, combinatory possibilities, and pervasiveness of its metapragmatic indexes. The interpretation of the trial data has been grounded on the details of linguistic form, the conditions of participation, and elements of identity and social relationships.

A broad definition of metapragmatics allowed us to view it as a general phenomenon of language use which comprises very diverse manifestations and works in overlapping strata. The data revealed that metapragmatic indexing is constitutive of the genre 'closing argument'. Five types of indexes have been identified. They range from the lowest-stratum primary performative expressions to the highest-stratum co- 
occurring features of style, and include evaluations of speech, descriptions of the social practice, and signals of contextual conditions. The heterogeneity of these features results in various degrees of saliency of their rhetorical potential; thus, evaluative formulations of previous speech and stylistic characteristics such as repetitions or triplets, for example, contribute to the persuasiveness of the closing argument more clearly than other types of metapragmatic elements. Likewise, there are various degrees in which these features serve the trial lawyer's self-presentation or alignment with powerful participants. Both the descriptions of trials in the abstract or of the trial in progress and the references to the court or other lawyers lend themselves more than the other features to help position the speaker favorably. It can be argued, however, that a basic general function is shared by the heterogeneous set of metapragmatic elements in a closing argument: That of legitimating the trial lawyer's performance as one that fits the professional role, the speech event, the state institution, and the social networks to which the expert participants belong.

With the kind of performatives described in this paper, trial lawyers enact their institutional and professional identities, but more importantly, they actively perpetuate institutional and professional roles, and structural positions in their social field. Most labels for previous speech of the kind found in the data are recognizably emblematic in the speech community of the category of social actors observed in this study. The trial lawyer's professional knowledge and competence are indexed by reference to legal principles and the rules of the criminal process, and at the same time, this explicitness re-establishes them and ratifies the legal community's ideas about the practice of administering criminal law. The strategic references to some contextual conditions, particularly participants, are an opportunity for identification moves which define the in-group as inclusive of all law practitioners or of the judges and lawyers in the trial which is being carried out. Finally, speech is stylistically designed to fit the communicative goals and setting, but at the same time, it indexes the expertise of the speaker, the courtroom, and the type of event. All these kinds of indices jointly signal that user is legitimately acting as a lawyer and participating in a criminal trial. That amounts to indexing a social position (with concomitant interests) within the legal field.

The inquiry about the overarching social meaning that gets expressed through metapragmatic elements led to the finding that metapragmatics has a specific social field functioning. In closing arguments, metapragmatics indexes membership to and positions in a social field of the law, with the resulting positioning of others as not belonging to the legal field.

This opens up a line of inquiry of other practices. On the one hand, if metapragmatics is constitutive of the social practice that it signals, then, research will show how it intervenes, in its multiple shapes, in the performance and identification of the practices. On the other hand, the habitual and ritual aspects of metapragmatic indexing indicate that it contributes to the symbolic delimitation of the social field to which the sociocultural practice belongs. Therefore, future studies may find that it is a resource in the struggles to preserve the structure of the social space.

\section{References}

Amsterdam, A., and R. Hertz (1992) An analysis of closing arguments to a jury. New York Law School Law Review 37: 55-122. 
Austin, J. (1962) How to do things with words. Oxford: Clarendon.

Bateson, G. (1972 [1955]) A theory of play and fantasy. In Steps to an ecology of mind. New York: Ballantine, pp. 177-193.

Bauman, R. (2001) The ethnography of genre in a Mexican market: Form, function, variation. In P. Eckert \& J. Rickford (eds.), Style and sociolinguistic variation. Cambridge: Cambridge University Press, pp. 57-77.

Bauman, R., and C. Briggs (1990) Poetics and performance as critical perspectives on language and social life. Annual Review of Anthropology 19: 59-88.

Bell, A. (1984) Language style as audience design. Language in society 13.2: 145-204.

Bell, A. (2001) Back in style: Reworking audience design. In P. Eckert \& J. Rickford (eds.), Style and sociolinguistic variation. Cambridge: Cambridge University Press: pp. 139-169.

Briggs, C. (1993) "I'm not just talking to the victims of oppression tonight - I'm talking to everybody": Rhetorical authority in an African American Poetics of political engagement. Journal of narrative and life history 3.1: 33-78.

Bourdieu, P. (1977) Outline of a theory of practice. Tr. Richard Nice. Cambridge: Cambridge University Press.

Bourdieu, P. (1990) In other words: Essays toward a reflexive sociology. Tr. Matthew Adamson. Stanford: Stanford University Press.

Bourdieu, P. (1998) Rethinking the State: Genesis and Structure of the Bureaucratic Field. Practical reason. On the theory of action. Stanford, CA: Stanford University Press, pp. 35-63. [orig. 1991, Sociological theory $12(1)]$.

Cameron, D. (2004) Out of the bottle: The social life of metalanguage. In A. Jaworski, N. Coupland \& D. Galasinski (eds.), Metalanguage. Social and ideological perspectives. Berlin/New York: Mouton de Gruyter, pp. 311-321.

Carranza, I.E., M.L. Rosenbaun, \& C. Barreras (2001) Intertextualidad en la incorporación de declaraciones por su lectura. In C. Lista, M. I Bergoglio \& M. Díaz de Landa (eds.), Cambio social y derecho: Debates y propuestas sociológicas en los inicios del siglo XXI. Córdoba: Editorial Triunfar, pp. $579-585$.

Carranza, I.E. (2003) Genre and Institution: Narrative temporality in final arguments. Narrative inquiry 13.1: 41-69.

Carranza, I.E. (2004) Discourse markers in the construction of the text, the activity, and the social relations: Evidence from courtroom discourse. In R. Márquez \& M. E. Placencia (eds.), Current Trends in the Pragmatics of Spanish. Amsterdam/New York: John Benjamins Publishing Company, pp. 203-227.

Carranza, I.E. (2006) Face, social practices, and ideologies in the courtroom. In M.E. Placencia \& C. García (eds.), Research on politeness in the Spanish-speaking world. Mahwah, N.J.: Lawrence Erlbaum, pp. 163-187.

Carranza, I.E. (2007) La ideología del texto verdadero. Páginas de Guarda. Buenos Aires: Universidad Nacional de Buenos Aires 2: 33-46.

Chouliaraki, L., and N. Fairclough. (1999) Discourse in late modernity. Edinburgh: University of Edinburgh Press. 
Conley, J.M., and W.O’Barr. (1990) Rules and relationships. Chicago: The University of Chicago Press.

Conley, J.M., and O'Barr (1998) Just Words. Law, language and power. Chicago/London: The University of Chicago Press.

Cotterill, J. (1998) "If it doesn't fit, you must acquit": Metaphor and the O J Simpson criminal trial. Forensic linguistics 5.2: 141-158.

Cotterill, J. (2003) Language and power in court: A linguistic analysis of the O.J. Simpson Trial. Houndmills: Palgrave.

Cotterill, J. (2004) Collocation, connotation, and courtroom semantics: Lawyers' control of witness testimony through lexical negotiation. Applied linguistics 25.4: 513-537.

Danet, B. (1997) Speech, writing and performativity: An evolutionary view of the history of constitutive ritual. In B.-L. Gunnarson, P. Linell, \& B. Nordberg, (eds.), The construction of professional discourse. London/New York: Longman, pp. 13-41.

Duranti, A. (1996) Linguistic anthropology. Cambridge: Cambridge University Press.

Eades, D. (2006) Lexical struggle in court: Aboriginal Australians versus the state. Journal of Sociolinguistics 10.2: 153-180.

Gal, S., and K. Woolard (1995) Constructing languages and publics: Authority and representation. Pragmatics 5.2: 129-138.

Hanks, W. (1996) Language and communicative practices. Boulder, CO: Westview.

Hobbs, P. (2003) Is that what we're here about? A lawyer's use of impression management in a closing argument at trial. Discourse \& Society 14.3: 273-290.

Jacobson, R. (1960) Closing statement: Linguistics and poetics. In T.A. Sebeok (ed.), Style in language. Cambridge, MA: MIT Press, pp. 350-377.

Jacquemet, M. (1996) Credibility in court. Communicative practices in the Camorra trials. Cambridge: Cambridge University Press.

Jaworski, A., N. Coupland \& D. Galasinski. (eds.) (2004) Metalanguage. Social and ideological perspectives. Berlin/New York: Mouton de Gruyter.

Lucy, J.A. (1993) Reflexive language and the human disciplines. In J.A. Lucy (ed.), Reflexive Language. Reported speech and metapragmatics. Cambridge: Cambridge University Press, pp. 9-32.

Matoesian, G. (1993) Reproducing Rape Domination through Talk in the Courtroom. Chicago: University of Chicago Press.

Matoesian, G. (2001) Law and the Language of Identity: Discourse in the William Kennedy Smith Rape Trial. Oxford, UK: Oxford University Press.

Mertz, E. (1994) Legal language: Pragmatics, poetics, and social power. Annual Review of Anthropology. 23: 435-455.

Mertz, E. (1998) Linguistic ideology and praxis in US law school classroom. In B. Shiefflin, K. Woolard, \& P.V. Kroskrity (eds.), Language ideologies. New York/Oxford: Oxford University Press, pp. 140-162.

Preston, D.R. (2004) Folk metalanguage. In A. Jaworsky, N. Coupland and D. Galasinski (eds.), Metalanguage. Social and ideological perspectives, pp. 75-101. 
Silverstein, M. (1993) Metapragmatic discourse and metapragmatic function. In Reflexive languag, indirect discourse and metapragmatics. In J.A. Lucy (ed.), Cambridge: Cambridge University Press, pp. $33-58$.

Stygall, G. (1994) Trial language. Differential discourse processing and discursive formation. Amsterdam/Philadelphia: John Benjamins Publishing Company.

Tiersma, P. (1999) Legal language. Chicago: University of Chicago Press.

Verschueren, J. (1999) Understanding pragmatics. London: Arnold.

Verschueren, J. (2000) Notes on the role of metapragmatic awareness in language use. Pragmatics 10.4: $439-456$.

\section{Appendix 1: Transcription conventions}

Bold letters indicate phenomena being analyzed.

Underlining indicates phenomena which are discussed in a different section.

: lengthened syllable

. falling tone

, rising tone

.. intraturn pause

CAPS increased loudness

( ) unclear

(( )) transcriber's comments

* dialectal word stress

The stop and the comma are not used as intonation symbols in the English translation of the examples, but as punctuation marks. 